\title{
Testing the Extraction of DNA from Human Teeth Exposed to Different Chemical Solutions
}

\author{
Prueba de Extracción de ADN de Dientes Humanos \\ Expuestos a Diferentes Soluciones Químicas
}

\begin{abstract}
Nicole Prata Damascena1; Moezio de Vasconcellos Costa Santos Filho²; Gustavo Reis Branco de Souza2; Luiz Antonio Ferreira da Silva²; Charles dos Santos Estevam; Ademir Franco3; Luiz Renato Paranhos"; Jamilly de Oliveira Musse ${ }^{5}$
\end{abstract}

DAMASCENA, N. P.; SANTOS-FILHO, M. V. C. ; DE SOUZA, G. R. B.; DA SILVA, L. A. F.; ESTEVAM, C. S.; FRANCO, A.; PARANHOS, L. R. \& MUSSE, J. O. Testing the extraction of DNA from human teeth exposed to different chemical solutions. Int. J. Odontostomat., 11(2):173-177, 2017.

ABSTRACT: The aim of this study was to evaluate the extraction of dental DNA exposed to different chemical solutions. The sample was composed by 15 subjects, from which 5 samples of oral mucosal cells (reference population) and 15 teeth (experimental population) were collected. The experimental population was divided in three equal parts, which were exposed to different chemical solutions, namely hydrochloric acid $(\mathrm{HCl})$ at $37 \%$, formaldehyde $\left(\mathrm{CH}_{2} \mathrm{O}\right)$ at $10 \%$ and sodium hypochlorite $(\mathrm{NaOCl})$ at $2.5 \%$. The DNA from the oral mucosa was extracted using organic method, while the dental DNA was extracted using the AFDIL method, including amplification by PCR and sequencing through capillary electrophoresis. The DNA exposed to hydrochloric acid dissolved, lacking extraction. The exposure of teeth to formaldehyde and sodium hypochlorite did not interfere in the extraction of DNA, once the amplification was visible in both experimental populations. The present outcomes demonstrated that DNA extraction may be limited under exposure to chemical solutions.

KEY WORDS: forensic sciences, forensic dentistry, tooth, DNA.

\section{INTRODUCTION}

Forensic science relies mainly on three scientific pathways for human identification: fingerprints, teeth and DNA analyses (Senn \& Weems, 2013). Each of these pathways is founded on comparative procedures, in which the post-mortem (PM) data of the deceased victim is compared with the ante-mortem (AM) data of missing persons (Senn \& Weems). Advantages and limitations are inherent to these human identification pathways. In one hand, fingerprint analysis is a quick and low cost procedure compared to the other pathways (Uchida, 2005), while in the other hand it may not be feasible when the soft tissues are damaged by external factors (Silva et al., 2015), such as in charred and putrefied bodies. Similarly, dental analysis is also a quick and low cost procedure, but it also has the advantage of relying in the integrity of the teeth - which are the most durable part of the human body (Belotti et al., 2015). However, this analysis depends on the availability of dental records for a comparative procedure (Kavitha et al., 2009), which may not exist in populations without access to dental treatment. The DNA analysis is performed screening the genetic profile of the victim and matching it with genetic profiles of a potential candidate. Over the last decade, this approach became the gold standard for human identification (Guimarães et al., 2009), but financial and methodological limitations remained related to its applicability (Guimarães et al.). These limitations include the high cost of the procedure and the lack of preservation of DNA samples in human remains in certain circumstances, respectively.

${ }^{1}$ Department of Physiology, Federal University of Sergipe, Brazil.

2 Institute of Biological and Health Science, Federal University of Alagoas, Brazil.

${ }^{3}$ Department of Stomatology, Federal University of Paraná, Brazil.

${ }^{4}$ Department of Dentistry, Federal University of Sergipe, Brazil.

${ }^{5}$ Department of Health, Federal University of Feira de Santana, Brazil. 
Increasing violence rates followed by enlarged number of violent deaths and qualified crimes are observed nowadays (Silva et al.). Bodies that undergo intentional PM alterations, such as carbonization and dissolution, appeared more often in this scenario. Consequently, forensic investigations are potentially hampered by the degradation of DNA due to high temperature and acid $\mathrm{pH}$ (Schwartz et al., 1991), respectively. Technological advances in the forensic science became gradually necessary towards the improvement of evidence collection and analysis. The human teeth represented for DNA analysis a biologic "armor" that preserves the genetic information (Girish et al., 2010), eventually resisting to adverse PM alterations. Based on that, testing the collection of DNA from the human teeth in adverse conditions could contribute significantly to the field of forensic genetics.

The present research was conducted to evaluate the extraction and amplification of DNA from human teeth immersed in hydrochloric acid at $37 \%$, formaldehyde at $10 \%$ and sodium hypochlorite at $2.5 \%$.

\section{MATERIAL AND METHOD}

Ethical criteria. The present research was performed after the approval of the Committee of Ethics in Research of the Federal University of Sergipe (CEP/ UFS), under the protocol number 01260107000-10, complying with the Declaration of Helsinki.

Sample description. This experimental study was performed with a sample of 15 subjects, who underwent the extraction of a single tooth (experimental population, $n=15$ ). The dental extractions were performed in a university environment by a dental surgeon following therapeutic indications. The inclusion criteria consisted of the absence of caries or restorative material clinically detectable in the teeth. The exclusion criteria consisted of teeth surgically sectioned during the extraction. A control group was created by collecting samples of oral mucosal cells from 5 of the previous subjects (control population, $n=5$ ).

After cleaning, the teeth of the experimental population were divided into 3 equal groups. Group 1 was immersed in $25 \mathrm{~mL}$ of hydrochloric acid $(\mathrm{HCl})$ at 37 $\%$; Group 2 was immersed in $25 \mathrm{~mL}$ of formaldehyde $(\mathrm{CH} 2 \mathrm{O})$ at $10 \%$; and Group 3 was immersed in $25 \mathrm{~mL}$ of sodium hypochlorite $(\mathrm{NaOCl})$ at $2.5 \%$. The teeth remained immersed in the chemical solutions for 4 days, complying with the protocol of previous studies (Danesino et al., 1998; Mazza et al., 2005; Jahdav et al., 2009).

DNA extraction, amplification and analysis. After four days the teeth underwent cryogenic pulverization with liquid nitrogen in freezer MILL. The extraction of dental DNA was performed according to the Armed Forces DNA Identification Laboratory (AFDIL), while the extraction of DNA from the oral mucosa was performed using the organic method with phenol/ chloroform solution and precipitation with isopropanol.

All the samples were amplified through polymerase chain reaction (PCR), using the Identifiler kit (Applied Biosystems ${ }^{\circledR}$, Waltham, USA) with the following molecular markers: D18S51, D21S11, TH01, D3S1358, FGA, TPOX, D8S1179, vWA, CSF1PO, D16S539, D7S820, D13S317, D5S818 and amelogenin. The adopted cycling protocol consisted of two minutes at $95{ }^{\circ} \mathrm{C}$ for initial denaturation; one minute at $94^{\circ} \mathrm{C}$ for denaturation; one minute at $60^{\circ} \mathrm{C}$ for hybridization; and one minute at $72{ }^{\circ} \mathrm{C}$ for extension - resulting in a total of 30 cycles (Butler, 2005). The PCR products were analyzed and sequenced by capillary electrophoresis (Butler) using the ABI 3100 Genetic Analyzer (Applied Biosystems ${ }^{\circledR}$, Waltham, USA). The analysis of amplified alleles was performed using GeneMapper software (Applied Biosystems ${ }^{\circledR}$, Waltham, USA) version 3.7.0. The results were tabulated and reported in descriptive statistics.

\section{RESULTS AND DISCUSSION}

Teeth are selected as source of DNA material mainly due to the high durability found in its structures (enamel, cementum and dentin), which often succeeds in preserving the integrity of genetic material. The durability of the human teeth plays an important part resisting to natural and PM alterations induced by men (Vieira et al., 2010; Manjunath et al., 2011), such as putrefaction and carbonization, respectively. Cadaveric alterations evolved following the current changes in criminality, which includes more complex mechanisms compared to decades ago. Criminals are more aware of crime scene investigations. Consequently, they became more concerned of vanishing forensic evidences. The present research simulated a cadaveric alteration induced by men. In the simulation used in this research, human teeth were immersed in $\mathrm{HCl}$ at $37 \%$ (Group 1), which is a chemical acid solution used to hamper the identification process. The samples of 
human teeth were also immersed in $\mathrm{CH} 2 \mathrm{O}$ at $10 \%$ (Group 2) and $\mathrm{NaOCl}$ at $2.5 \%$ (Group 3), which are chemicals solutions used for cleaning purposes.

Table I. Genetic profile of the samples of oral mucosal cells.

\begin{tabular}{lccccc}
\hline \multicolumn{1}{c}{ Loci } & 1 & 2 & 3 & 4 & 5 \\
\hline Amel & $\mathrm{XX}$ & $\mathrm{XY}$ & $\mathrm{XX}$ & $\mathrm{XX}$ & $\mathrm{XX}$ \\
\hline CSF1PO & $12 / 13$ & $12 / 12$ & $11 / 12$ & $12 / 13$ & $10 / 12$ \\
D12S391 & $21 / 21$ & $18 / 20$ & $18 / 18$ & $19 / 19$ & $17 / 18$ \\
D13S317 & $9 / 12$ & $9 / 12$ & $11 / 12$ & $11 / 12$ & $12 / 14$ \\
D16S539 & $10 / 12$ & $10 / 13$ & $12 / 12$ & - & $10 / 10$ \\
D18S51 & $12 / 14$ & $12 / 15$ & $14 / 19$ & $18 / 18$ & $12 / 15$ \\
D19S433 & $12 / 13$ & $12 / 13$ & $15 / 16$ & $13.2 / 16$ & $13 / 13$ \\
D2S1338 & $20 / 23$ & $18 / 18$ & $19 / 24$ & $16 / 19$ & $17 / 19$ \\
D3S1358 & $14 / 16$ & $15 / 18$ & $15 / 19$ & $14 / 16$ & $15 / 15$ \\
D5S818 & $10 / 12$ & $12 / 13$ & $9 / 11$ & $9 / 13$ & $11 / 13$ \\
D7S820 & $8 / 12$ & $7 / 8$ & $10 / 12$ & $10 / 11$ & $10 / 11$ \\
D8S1179 & $9 / 15$ & $11 / 13$ & $13 / 13$ & $12 / 13$ & $14 / 14$ \\
FGA & $20 / 22$ & $21 / 22$ & $24 / 26$ & $22 / 24$ & $21 / 23$ \\
SE33 & $18 / 26$ & $23.2 / 24$ & $18 / 26$ & $18 / 28$ & $22.2 / 23$ \\
TH01 & $8 / 9$ & $8 / 9.3$ & $8 / 9$ & $7 / 9.3$ & $8 / 10$ \\
TPOX & $8 / 8$ & $8 / 8$ & $8 / 8$ & $9 / 10$ & $10 / 12$ \\
vWA & $16 / 17$ & $15 / 17$ & $15 / 19$ & $14 / 15$ & $15 / 17$ \\
\hline NUmbers & & & & &
\end{tabular}

Numbers from 1 to 5 accounts for each of the teeth sampled in the control group, which are divided horizontally in face of the Loci examined in the present study.
The teeth in Group 1 were entirely dissolved, making the DNA extraction completely unfeasible. This phenomenon is justified by the chemical interaction $(\mathrm{Ca}+2+2 \mathrm{HCl} Æ \mathrm{E} \mathrm{CaCl} 2+\mathrm{H} 2)$ that occurred along the 4 days of experiment. This interactive chemical reaction between the acid and the dental calcium led to the formation of salt (calcium chloride), which is soluble in water (Danesino et al.; Jeffery et al., 2000). DNA amplification was observed within the peaks of molecular markers in all the dental samples extracted. This finding suggests that the chemical solutions used in this research did not interfere directly in this process during the time interval of 4 days. As expected, all the samples of oral mucosal cells (control Group) were also visualized (Table I). Differently, the association between formaldehyde and the degradation of DNA is controversial in the scientific literature. While studies suggest that formaldehyde does not affect DNA molecules, others claim the opposite. The last indicates that formaldehyde is a potential agent in DNA degradation considering the interaction of lysine and arginine amino acids (Gusmman et al., 2007). In the present study, formaldehyde did not interfere within DNA molecules (Table II). Similarly, no influence of sodium hypochlorite was observed in DNA as well, once the amplification outcomes were optimal (Table III). However, these outcomes confront the scientific

Table II. Genetic profile of the samples of teeth immersed in formaldehyde at $10 \%$

\begin{tabular}{lccccc}
\hline \multicolumn{1}{c}{ Loci } & $\mathbf{1}$ & $\mathbf{2}$ & $\mathbf{3}$ & $\mathbf{4}$ & $\mathbf{5}$ \\
\hline Amel & $\mathrm{XY}$ & $\mathrm{XX}$ & $\mathrm{XY}$ & $\mathrm{XX}$ & $\mathrm{XX}$ \\
\hline CSF1PO & - & $12 / 13$ & $12 / 12$ & - & - \\
D12S391 & - & $21 / 21$ & $18 / 20$ & $19 / 19$ & - \\
D13S317 & $11 / 14$ & $12 / 14$ & $12 / 14$ & $12 / 12$ & $12 / 12$ \\
D16S539 & - & - & - & - & - \\
D18S51 & - & $12 / 14$ & $12 / 15$ & - & - \\
D19S433 & $12 / 14$ & $12 / 13$ & $12 / 13$ & $13.2 / 16$ & $15 / 16$ \\
D2S1338 & $17 / 17$ & $20 / 23$ & $18 / 24$ & $16 / 19$ & - \\
D3S1358 & $17 / 17$ & $14 / 16$ & $15 / 18$ & $14 / 16$ & $15 / 15$ \\
D5S818 & $11 / 13$ & $10 / 12$ & $12 / 13$ & $9 / 13$ & - \\
D7S820 & $10 / 11$ & $8 / 12$ & $7 / 8$ & $10 / 10$ & - \\
D8S1179 & - & $15 / 15$ & - & - & - \\
FGA & - & $20.2 / 22$ & $21 / 22$ & - & - \\
SE33 & $16 / 26$ & $18 / 26$ & $23.2 / 23$ & $18 / 28$ & - \\
TH01 & - & $8 / 9$ & $8 / 9.3$ & $7 / 7$ & $8 / 9$ \\
TPOX & - & $8 / 8$ & - & - & - \\
vWA & $16 / 17$ & $16 / 17$ & $15 / 17$ & $14 / 15$ & $15 / 19$ \\
\hline
\end{tabular}

Numbers from 1 to 5 accounts for each of the teeth sampled in Group 2, which are divided horizontally in face of the Loci examined in the present study. 
DAMASCENA, N. P.; SANTOS-FILHO, M. V. C. ; DE SOUZA, G. R. B.; DA SILVA, L. A. F.; ESTEVAM, C. S.; FRANCO, A.; PARANHOS, L. R. \& MUSSE, J. O. Testing the extraction of DNA from human teeth exposed to different chemical solutions. Int. J. Odontostomat., 11(2):173-177, 2017.

Table III. Genetic profile of the samples of teeth immersed in sodium hypochlorite at $2.5 \%$.

\begin{tabular}{lccccc}
\hline \multicolumn{1}{c}{ Loci } & 1 & 2 & 3 & 4 & 5 \\
\hline Amel & $\mathrm{XY}$ & $\mathrm{XX}$ & - & $\mathrm{XX}$ & $\mathrm{XY}$ \\
\hline CSF1PO & $11 / 12$ & $7 / 10$ & - & $10 / 12$ & $9 / 10$ \\
D12S391 & $15 / 17$ & $17 / 20$ & - & $17 / 18$ & $16 / 18$ \\
D13S317 & $11 / 12$ & $12 / 14$ & $12 / 12$ & $12 / 13$ & $11 / 14$ \\
D16S539 & $11 / 11$ & $9 / 9$ & - & - & $9 / 10$ \\
D18S51 & $13 / 13$ & $15 / 16$ & - & $12 / 15$ & $11 / 12$ \\
D19S433 & $15 / 15$ & $12 / 14$ & - & $13 / 15$ & $12 / 14$ \\
D2S1338 & $17 / 20$ & $18 / 23$ & - & $17 / 19$ & $17 / 24$ \\
D3S1358 & $16 / 17$ & $14 / 15$ & $14 / 14$ & $14 / 15$ & $17 / 17$ \\
D5S818 & $11 / 13$ & $12 / 12$ & - & $11 / 11$ & $11 / 13$ \\
D7S820 & $10 / 11$ & $10 / 12$ & $12 / 12$ & $10 / 11$ & $10 / 11$ \\
D8S1179 & $13 / 14$ & $9 / 11$ & - & $14 / 14$ & $14 / 14$ \\
FGA & $24 / 24$ & $20 / 25$ & $19 / 19$ & $21 / 23$ & $22 / 24$ \\
SE33 & $16 / 27$ & $17 / 31$ & - & $22.2 / 23.2$ & $16 / 26$ \\
TH01 & $9.3 / 10$ & $9.3 / 10$ & - & $8 / 9.3$ & $6 / 7$ \\
TPOX & $8 / 8$ & $10 / 10$ & - & $10 / 12$ & $8 / 12$ \\
Vwa & $16 / 18$ & $15 / 16$ & - & $15 / 17$ & $16 / 17$ \\
\hline
\end{tabular}

Numbers from 1 to 5 accounts for each of the teeth sampled in Group 3 , which are divided horizontally in face of the Loci examined in the present study.

literature. More specifically, sodium hypochlorite is known by its deleterious effect in DNA molecules. This interaction is expressed by the formation of chlorinated derivatives of nucleotide bases, as well hydrolysis and degradation of amino acids due to the involvement of hypochlorous acid and hypochlorite ions.

Despite simulating a problem-based situation in forensic sciences, the present study did not include aspects found in real scenarios, such as the oral soft and hard tissues adjacent to the teeth that protect them against the chemical substances. Moreover, the time set for the experiment was fixed in 4 days. Further studies are necessary in the field to test the influence of 1) protection tissues adjacent to the teeth (e.g. performing animal studies) and 2) time variations (e.g. setting longitudinal studies). In general terms, the present research provided a technical observation on the extraction of DNA from teeth found in complex circumstances, simulating the new trend of evolved criminal mechanisms against the forensic evidence.

DAMASCENA, N. P.; SANTOS-FILHO, M. V. C. ; DE SOUZA, G. R. B.; DA SILVA, L. A. F.; ESTEVAM, C. S.;
FRANCO, A.; PARANHOS, L. R. \& MUSSE, J. O. Prueba de extracción de ADN de dientes humanos expuestos a diferentes soluciones químicas. Int. J. Odontostomat., 11(2):173-177, 2017.

RESUMEN: El objetivo de este estudio fue evaluar la extracción de ADN dental expuesto a diferentes soluciones químicas. La muestra estuvo compuesta por 15 sujetos, de los cuales se recogieron 5 muestras de células de la mucosa oral (población de referencia) y 15 dientes (población experimental). La población experimental se dividió en tres partes iguales, que fueron expuestas a diferentes soluciones químicas, a saber, ácido clorhídrico $(\mathrm{HCl})$ al $37 \%$, formaldehído $\left(\mathrm{CH}_{2} \mathrm{O}\right)$ al $10 \%$ e hipoclorito de sodio $(\mathrm{NaOCl})$ al 2,5 \%. El $A D N$ de la mucosa oral se extrajo utilizando el método orgáni$\mathrm{co}$, mientras que el ADN dental se extrajo utilizando el método AFDIL, incluyendo la amplificación por PCR y la secuenciación a través de electroforesis capilar. EI ADN expuesto al ácido clorhídrico se disolvió, careciendo de extracción. La exposición de los dientes al formaldehído e hipoclorito de sodio no interfirió en la extracción de ADN, una vez que la amplificación era visible en ambas poblaciones experimentales. Los resultados actuales demostraron que la extracción de ADN puede ser limitada bajo la exposición a soluciones químicas.

PALABRAS CLAVE: ciencias forenses, odontología forense, dientes, ADN. 
DAMASCENA, N. P.; SANTOS-FILHO, M. V. C. ; DE SOUZA, G. R. B.; DA SILVA, L. A. F.; ESTEVAM, C. S.; FRANCO, A.; PARANHOS, L. R. \& MUSSE, J. O. Testing the extraction of DNA from human teeth exposed to different chemical solutions. Int. J. Odontostomat., 11(2):173-177, 2017.

\section{REFERENCES}

Belotti, L.; Rabbi, R.; Pereira, S. D. R.; Barbosa, R. S.; Carvalho, K. S. \& Pacheco, K. T. S. Is it possible to identify positively a charred body using only two teeth? a forensic case report. Rev. Bras. Odontol. Leg., 2(2):105-15, 2015.

Butler, J. M. Forensic DNA typing: Biology, Technology, and Genetics Of STR Markers. $2^{\text {nd }}$ ed. San Diego, Elsevier Academic Press, 2005.

Danesino, P.; Alonzo, M. \& Carlesi, G. Experimental evaluation of the biological samples dissolution performed by three different acids: preliminary results. Arch. Med. Leg., 1(1):23-6, 1998.

Girish, K. L.; Rahman, F. S. \& Tippu, S. R. Dental DNA fingerprinting in identification of human remains. J. Forensic Dent. Sci., 2(2):638, 2010.

Guimarães, M. A.; Soares-Vieira, J. A.; da Silva, R. H. A. \& Evison, M. P. A standard procedure for accommodating forensic anthropological and genetic analysis of decomposing human remains from tropical climates. Forensic Sci. Int. Genet. Suppl. Ser., 2(1):165-6, 2009.

Gusmman, T. A disorder in DNA by action of formalin. Scrabber Rev. Genetic, 1:232-3, 2007.

Jadhav, K.; Gupta, N.; Mujib Ahmed, B. R. \& Amberkar, V. S. Effect of acids on the teeth and its relevance in postmortem identification. J. Forensic Dent. Sci., 1(2):93-8, 2009.

Jeffery, G. H.; Bassett, J.; Mendham, J. \& Denney, R.C. Vogel's Textbook of Quantitative Chemical Inorganic Analysis. $6^{\text {th }}$ ed. Upper Saddle River, Prentice Hall, 2000.

Kavitha, B.; Einstein, A.; Sivapathasundharam, B. \& Saraswathi, T. R. Limitations in forensic odontology. J. Forensic Dent. Sci., 1(1):810, 2009

Manjunath, B. C.; Chandrashekar, B. R.; Mahesh, M. \& Vatchala Rani, R. M. DNA profiling and forensic dentistry-a review of the recent concepts and trends. J. Forensic Leg. Med., 18(5):191-7, 2011.

Mazza, A.; Merlati, G.; Savio, C.; Fassina, G.; Menghini, P. \& Danesino, P. Observations on dental structures when placed in contact with acids: experimental studies to aid identification processes. J. Forensic Sci., 50(2):406-10, 2005.

Schwartz, T. R.; Schwartz, E. A.; Mieszerski, L.; McNally, L. \& Koblinsky, L. Characterization of deoxyribonucleic acid (DNA) obtained from teeth subjected to various environmental conditions. J. Forensic. Sci., 36(4):979-90, 1991.

Senn, D. R. \& Weems, R. A. Manual of Forensic Odontology. $5^{\text {th }}$ ed. Boca Raton, C. R. C. Press, 2013.

Silva, R. F.; Dias, P. E. M.; Picoli, F. F.; Rodrigues, L. G.; Mundim, M. B. V. \& Franco, A. Anthropological discrepancies detected in putrefied body identified with dental records - a case report. Rev. Bras. Odontol. Leg., 2(1):125-36, 2015.

Uchida, K. Fingerprint identification. NEC J. Adv. Technol., 2(1):1927, 2005.

Vieira, G. S.; Tavares, C. A. P. \& Bouchardet, F. C. H. Análise de DNA em odontologia forense. Arq. Bras. Odontol., 6(2):64-70, 2010.
Corresponding author:

Nicole Prata Damascena

Department of Physiology

Sergipe Federal University

Orlando Magalhães Maia 1330, Ap. 702

Grageru, Aracaju

Sergipe

Postal Code: 49025-530

BRAZIL

E-mail: nicoledamascena@gmail.com

Received: 30-11-2016

Accepted: 07-04-2017 